\title{
PERSEPSI SISWA TERHADAP PEMBELAJARAN BAHASA INDONESIA DARING PADA MASA PANDEMI COVID-19
}

\author{
Purwanto \\ SMP Negeri 44 Surabaya \\ purwanto@smpn44surabaya.sch.id
}

\begin{abstract}
Abstrak
Penelitian ini bertujuan untuk mengetahui persepsi siswa terhadap pemelajaran Bahasa Indonesia secara daring (online) pada masa pandemi Covid-19. Penelitian ini menggunakan metode analisis deskriptif kuantitatif dengan alat penelitian berupa kuesioner yang disebarkan secara online menggunakan Google Form. Jumlah sampel dalam penelitian ini adalah 40 siswa kelas $8 \mathrm{~B}$ yang mengikuti pembelajaran online selama masa pandemi Covid-19. Hasil penelitian menunjukkan bahwa 100\% siswa kelas 8B SMP Negeri 44 Surabaya menyelesaikan pembelajaran secara daring pada semester genap tahun ajaran 2020/2021. Media online yang paling diminati siswa selama pembelajaran secara daring adalah Google Classroom (40.5\%), WhatsApp (30.5\%), Zoom (19\%) dan Microsoft Teams (10\%). Meski begitu mayoritas siswa yakni $85 \%$ lebih memilih pemelajaran secara offline atau tatap muka daripada pembelajaran daring (online).
\end{abstract}

Kata Kunci: persepsi, pembelajaran daring, pandemic, Bahasa Indonesia

\begin{abstract}
This study aims to determine students' perceptions of learning Indonesian Language online during the Covid-19 pandemic. This study used a quantitative descriptive analysis method with a research tool in the form of a questionnaire distributed online using Google Form. The number of samples in this study were 40 grade $8 B$ students who took online learning during the Covid-19 pandemic. The results showed that 100\% of grade $8 B$ students of SMP Negeri 44 Surabaya completed online learning in the even semester of the 2020/2021 academic year. The most popular online media for students during online learning are Google Classroom (40.5\%), WhatsApp (30.5\%), Zoom (19\%) and Microsoft Teams (10\%). Even so, the majority of students, $85 \%$, prefer offline or face-to-face learning to online learning.
\end{abstract}

Keywords: perception, online learning, pandemic, Indonesian Language 


\section{PENDAHULUAN}

Pandemi Covid 19 sudah terjadi sejak bulan Desember Tahun 2019. Hingga saat ini, pandemi memberikan dampak yang besar di seluruh dunia dalam berbagai aspek, tidak terkecuali aspek pendidikan. Sejak Pertengahan bulan Maret 2020 hingga tahun 2021, Pemerintah Indonesia baik pusat hingga Pemerintah Daerah memberikan aturan untuk membatasi aktivitas bekerja, beribadah, dan belajar (Anhusadar, 2020). Peserta didik dikondisikan untuk belajar di rumah dan aktivitas pembelajaran di kelas untuk sementara waktu dihentikan beberapa saat (Fermiska dan Hutauruk, 2020). Sistem pembelajaran yang semula dilakukan secara tatap muka berganti dengan system pembelajaran jarak jauh (PJJ). Sistem PJJ atau yang biasa dikenal dengan istilah system pembelajaran daring merupakan pembelajaran yang dilakukan secara tidak langsung antara guru dan peserta didik melalui jaringan internet (Asmuni, 2020).

Terkait dampak penyebaran virus Covid-19 pada dunia pendidikan menuntut para pendidik dan peserta didik untuk mampu dengan cepat beradaptasi dengan perubahan yang ada. Sistem pembelajaran yang semula berbasis pada tatap muka secara langsung di kelas, harus digantikan dengan sistem pembelajaran yang terintegrasi melalui jaringan internet secara virtual (online-learning). Pembelajaran online menghubungkan pembelajar (peserta didik) dengan sumber belajarnya (database, pakar/instruktur, perpustakaan) yang secara fisik terpisah atau bahkan berjauhan namun dapat saling berkomunikasi, berinteraksi atau berkolaborasi (secara langsung atau synchronous dan secara tidak langsung atau asynchronous). Pembelajaran online merupakan bentuk pembelajaran/pelatihan jarak jauh yang memanfaatkan teknologi telekomunikasi dan informasi, misalnya internet (secara langsung dab tidak langsung) (Abidin \& Arizona, 2020).

Pembelajaran daring (online) menawarkan berbagai solusi di saat pembelajaran di kelas tradisional terganggu oleh pandemi Covid-19 (Dewi, 2020). Sistem pendidikan daring ini tidak hanya memiliki tantangan untuk tetap menjaga kualitas penyebarluasan pengetahuan, tanggung jawab, dan pengurangan biaya tetapi juga fleksibilitas bagi mereka yang bekerja (Toquero, 
2020). Oleh karena itu, pembelajaran daring harus berjalan secara efektif, segala hambatan seperti gangguan komunikasi, kompleksitas pembelajaran, dan kurangnya interaksi fisik dapat diatasi dengan memperkenalkan kerja kelompok daring, teknologi, pelatihan serta sistem virtual seperti laboratorium dan lingkungan kerja untuk meningkatkan keterampilan dan pengalaman pelajar (Chang, 2020). Pembelajaran daring ini memberikan manfaat bagi siswa maupun guru. Dalam pembelajaran daring, mendorong siswa untuk aktif berinteraksi dan belajar secara mandiri. Bagi guru, perubahan gaya mengajar dari konvensional (luring) memberikan tantangan tersendiri sebagai salah satu profesionalitas kerja dan juga peluang untuk menilai dan mengevaluasi perkembangan pembelajaran mahasiswa secara lebih efisien (Maulana, 2021).

Perkuliahan daring merupakan salah satu bentuk pemanfaatan internet yang dapat meningkatkan peran siswa dalam proses pembelajaran (Saifuddin, 2018). Istilah daring merupakan akronim dari "dalam jaringan". Jadi pembelajaran daring adalah salah metode pembelajaran online atau dilakukan melalui jaringan internet. Beberapa persyaratan pelaksanaan pembelajaran daring, antara lain: (a) pihak penyelenggara kegiatan kuliah daring, (b) mindset positif dosen dan siswa dalam fungsi utama internet, (c) desain sistem proses belajar yang bisa dipelajari oleh semua siswa, (d) adanya proses evaluasi dari rangkaian proses belajar siswa, dan (e) mekanisme feedback dari pihak penyelenggaraan (Mustofa, Chodzirin, Sayekti, \& Fauzan, 2019).

Hal yang terpenting dalam menerapkan pembelajaran daring pada siswa adalah seyogyanya memperhatikan berbagai aspek agar tujuan pembelajaran tercapai. Pembelajaran melalui sistem jaringan online ini sebagaimana dikemukakan Setyosari bahwa pembelajaran online/daring mencakup lima hal penting, yaitu: (1) isi yang disajikan memiliki relevansi dengan tujuan khusus pembelajaran yang ingin dicapai; (2) menggunakan metode-metode pembelajaran melalui contoh - contoh dan latihan-latihan untuk membantu belajar; (3) menggunakan media seperti gambargambar dan kata-kata untuk menyajikan isi dan metode, dan (4) mengembangkan dan membangun pengetahuan dan keterampilan baru sesuai dengan tujuan 
individu dan peningkatan organisasi (Abidin \& Arizona, 2020).

Pelaksanaan pembelajaran daring di SMP Negeri 44 Surabaya telah dilaksanakan selama masa pandemic Covid-19. Dengan kata lain pembelajaran di Semester Genap Tahun Akademik 2020-2021 di SMP Negeri 44 Surabaya menggunakan sistem daring. Selama proses pembelajaran daring belum diketahui dengan data valid mengenai persepsi siswa terkait kesiapan, kendala dan pelaksanaan pembelajaran daring. Peningkatan peran dan keaktifan siswa dalam penggunaan berbagai media dan teknologi demi suksesnya perkuliahan daring sangatlah dipengaruhi oleh persepsi (Nugroho, 2015).

Mayoritas penelitian terdahulu membahas mengenai persepsi peserta didik di masa awal pandemi sedangkan penelitian yang dilakukan di awal hingga di masa akhir pandemi seperti sekarang ini masih jarang dilakukan. Persepsi pembelajaran di awal pandemi dan akhir pandemi pasti memiliki perbedaan. Kajian terdahulu mengenai persepsi pembelajaran daring ini pernah dilakukan oleh beberapa penelitian. Penelitian pertama mengenai persepsi mahasiswa atas penggunaan aplikasi perkuliahan daring saat wabah Covid-19 (Mulyana, Rainanto, Astrini, \& Puspitasari, 2020). Penelitian kedua yaitu persepsi mahasiswa terhadap perkuliahan daring sebagai sarana pembelajaran selama masa karantina Covid-19 (Zhafira, dkk., 2020). Hal ini dikarenakan peneliti membutuhkan informasi dari siswa menengah pertama (SMP) khususnya di SMP Negeri 44 Surabaya tentang pembelajaran daring untuk perbaikan pembelajaran Bahasa Indonesia di semester berikutnya sehingga seluruh guru-guru yang ada di SMP Negeri 44 Surabaya dapat memperoleh acuan untuk pelaksanaan pembelajaran berikutnya.

Berangkat dari kebutuhan informasi dan menjawab beberapa pertanyaan tentang pelaksanaan pembelajaran di pandemi Covid-19, peneliti melakukan penelitian ini. Bagaimana kesiapan siswa dalam mendapatkan modus pembelajaran yang baru? Bagaimana penguasaan teknologi siswa untuk menggunakan sarana pembelajaran daring? Apa kendala dan evaluasi dari persiapan pembelajaran daring? Pertanyaan tersebut dijawab dalam hasil penelitian ini. Hal ini dapat dijadikan dasar untuk pelaksanaan pada 
pembelajaran di tahun akademik berikutnya. Tentunya, penelitian ini bertujuan untuk mengetahui persepsi siswa kelas 8B sebagai subjek dari penelitian ini terhadap pembelajaran Bahasa Indonesia yang dilakukan daring pada masa pandemi Covid-19.

\section{METODE}

Penelitian ini menggunakan pendekatan metode survei dengan sifat deskriptif yang memiliki tujuan untuk menggambarkan keadaan atau fenomena yang terjadi (Arikunto, 2010). Sudjana menyatakan bahwa penelitian deskriptif adalah pengujian yang dilaksanakan secara bertahap dimana peneliti mendeskripsikan satu atau beberapa gejala, perkara, kasus yang terjadi saat ini, mengambil masalah atau memusatkan perhatian kepada masalah-masalah aktual (Sudjana, 2012). Penelitian kualitatif deskriptif merupakan kegiatan penelitian dengan cara menganalisis, menggambarkan, dan meringkas berbagai kondisi, situasi dari berbagai data yang dikumpulkan berupa hasil wawancara atau pengamatan mengenai masalah yang diteliti yang terjadi di lapangan (Wirartha, 2006).
Survei dilakukan secara online melalui Google Form. Tercatat sebanyak 40 siswa kelas 8B di SMP Negeri 44 Surabaya yang telah berperan menjadi responden penelitian ini. Pemilihan subjek penelitian dilakukan dengan melalui teknik purposive sampling. Adapun kriteria siswa yang dilibatkan dalam penelitian ini adalah siswa kelas 8B yang aktif pada semester genap 2020/2021 yang sedang mengikuti perkuliahan daring. Pengumpulan data menggunakan metode kuesioner tertutup. Kuesioner penelitian ini terdiri dari 4 kelompok pertanyaan yang mewakili aspek keikutsertaan dalam perkuliahan daring, penggunaan media online/aplikasi pembelajaran daring, pilihan penggunaan aplikasi pembelajaran daring, serta hambatan pembelajaran daring. Selanjutnya data penelitian dianalisis menggunakan analisis kuantitatif deskriptif teknik persentase langsung dari Google Form.

\section{HASIL DAN PEMBAHASAN}

Pandemi Covid-19 memberikan dampak pada sekto Pendidikan dimana kebijakan pPemerintah menerapkan aturan Work from Home dan PSBB telah mendorong untuk menghentikan aktivitas akademis dan non-akademis di 
institusi pendidikan. Penghentian aktivitas tanpa ada alternatif pengganti akan menyebabkan siswa terhambat dalam proses menyelesaikan studinya. Pelaksanaan pembelajaran yang dilakukan secara daring menjadi alternatif utama pada masa pandemic Covid-19. Berbagai alternatif aplikasi dan platform pembelajaran secara daring digunakan dan disesuaikan dengan kondisi institusi masing-masing. Dalam penelitian ini, pembelajaran Bahasa Indonesia di SMP Negeri 44 Surabaya sejak pertengahan bulan Maret 2020 dilakukan secara daring. Berdasarkan survei melalui Google Form yang telah dilakukan diperoleh beberapa data mengenai keterlaksanaan, hambatan, penggunaan media online/platform, respon jika pembelajaran daring diperpanjang, perbandingan minat pembelajaran daring dan pembelajaran tatap muka.

Berdasarkan hasil respond pada Google Form, informasi bahwa 100\% siswa melaksanakan proses pembelajaran daring pada semester genap 2020/2021. Pada butir kuesioner selanjutnya diketahui media online yang digunakan pada pembelajaran daring beragam. Responden. Google Classroom menempati peringkat terbanyak pertama yaitu media online yang paling diminati siswa selama pembelajaran secara daring adalah Google Classroom (40.5\%), WhatsApp (30.5\%), Zoom (19\%) dan Microsoft Teams (10\%). Data tersebut bisa dilihat pada gambar berikut:

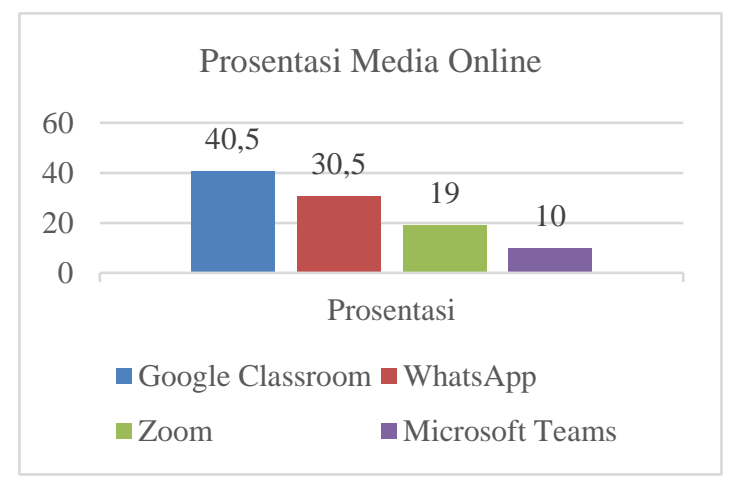

Selain kendala dalam pelaksanaan pembelajaran Bahasa Indonesia secara daring, siswa dan guru juga mengalami kendala dalam memahami/mengajarkan materi pembelajaran. Pada awal pandemic siswa dan guru masih memilih pembelajaran dilakukan secara luring disebabkan masih perlu banyak penyesuaian atau adaptasi. Banyak kesulitan yang dialami, diantaranya kesulitan dalam penggunaan media/platform yang digunakan, perubahan metode pembelajaran, alat dan fasilitas yang belum memenuhi, serta penguasaan teknologi yang belum mumpuni. 
Dari hasil penelitian yang telah diuraikan sebelumnya, dapat dinyatakan bahwa selama pandemi Covid-19, pembelajaran luring memang diminati di awal karena semua mahasiswa merasa kesulitan dengan berbagai persoalan yang muncul dan belum beradaptasi dengan kondisi yang ada. Pada pertengahan pandemi, sudah mulai beradaptasi walaupun masih belum sepenuhnya menerima keadaan.

Pada item kuesioner berikutnya memperlihatkan bahwa siswa lebih berminat belajar secara offline yaitu pembelajaran di kelas secara tatap muka dibandingkan dengan pembelajaran secara online di rumah. Hal ini berdasarkan data kuantitatif yang diperoleh bahwa $85 \%$ memilih belajar di kelas (offline), dan sisanya $15 \%$ memilih belajar di rumah (online).

Meskipun mayoritas siswa lebih memilih belajar di rumah secara tatap muka (offline), tetapi siswa tetap merasakan dampak positif dari pembelajaran daring. Sebanyak $45 \%$ siswa menyatakan kemudahan belajar di mana saja dan kapan saja, 30\% menyatakan lebih peka terhadap teknologi pembelajaran, $10 \%$ siswa menyatakan bahwa gaya belajar dapat diatur sendiri, $5 \%$ siswa merasakan efisiensi waktu, $5 \%$ siswa bisa belajar lebih tenang dan fokus, dan 5\% menyatakan semua dampak positif dari pembelajaran daring dirasakan oleh siswa.

Pernyataan $85 \%$ siswa yang menyatakan lebih suka belajar di kelas secara tatap muka (offline) dikuatkan oleh pernyataan siswa tentang hambatan yang alami selama pembelajaran daring (online) di rumah. Sebanyak $45.5 \%$ menyatakan bahwa siswa menjadi boros dengan kuota internet. Lalu $24.5 \%$ siswa menyatakan bahwa penjelasan materi oleh guru kurang maksimal. Kemudian $15 \%$ siswa menyatakan signal internet terbatas, $10 \%$ siswa menyatakan interaksi pembelajaran terbatas dan 5\% siswa menyatakan bahwa media pembelajaran daring sulit untuk diikuti.

Media online yang paling diminati saat pembelajaran Bahasa Indonesia secara daring yaitu Google Classroom dan tentunya untuk pembelajaran daring tentu saja beralasan. Pembelajaran daring dengan menggunakan Google Classroom dapat meningkatkan interaksi pada proses pembelajaran, dapat mengakses dan berkomunikasi dengan teman sekelas serta 
pengajarnya dengan mudah (Maskar \& Wulantina, 2019). Siswa memiliki persepsi yang positif tentang penggunaan Google Classroom. Tujuan pembelajaran juga tercapai. Martínez menyerukan integrasi analisis pembelajaran dengan Google Classroom karena mereka percaya bahwa ini adalah batasan utama dari alat yang muncul (Martínez-Monés, Reffay, Torío, \& Cristóbal, 2017). Google Classroom diluncurkan pada tahun 2014. Oleh karena itu, studi yang terkait dengan keefektifan Google Classroom telah dimulai. Shaharanee, Jamil, \& Rodzi (Shaharanee, Jamil, \& Rodzi, 2016) menganalisis aktivitas pembelajaran aktif Google Classroom. Mereka menggunakan TAM (Technology Acceptance Model) untuk mempelajari keefektifan aktivitas yang diposting di platform. Hasil dari 40 siswa mengungkapkan bahwa kinerja komparatif Google Classroom jauh lebih baik dalam bidang komunikasi, interaksi, manfaat yang dirasakan, kemudahan penggunaan, dan kepuasan siswa secara keseluruhan.

Kendala ini menjadi kendala paling sering ditemui pada pembelajaran daring. Sesuai dengan hasil penelitian Mulyana menunjukkan bahwa kendala mengikuti perkuliahan daring muncul oleh karena ketersediaan kuota akses internet yang tidak selalu ada. Ketersediaan kuota akses internet ini tidak selaras dengan adanya dukungan keluarga kepada siswa untuk selalu mengikuti pembelajaran daring. Keterbatasan kuota akses internet dipengaruhi oleh kesiapan sumberdaya yang dimiliki keluarga untuk para siswa. Tidak sedikit para siswa yang harus berhemat dalam penggunaan kuota akses internet. Mereka harus berbagi dengan pemenuhan kebutuhan sehari-hari yang lainnya. Salah satu penyebab keterbatasan sumber daya ini, adalah kondisi yang memaksa orang tuanya atau siswa yang bersangkutan tidak bekerja saat wabah Covid-19, sehingga tidak memiliki penghasilan (Mulyana et al., 2020).

Hambatan paling signifikan pembelajaran daring atau online ada di tingkat siswa termasuk kurangnya pengetahuan siswa dan keterampilan dalam penggunaan platform e-learning, dan kurangnya akses ke perangkat dan koneksi internet (Mailizar, Almanthari, Maulina, \& Bruce, 2020). Temuan sejenis dari penelitian lain yaitu mahalnya biaya untuk mengikuti pembelajaran online yang menunjukkan bahwa siswa menghabiskan 
begitu banyak uang membeli data internet untuk pembelajaran online.

Respon negatif yang dijawab mayoritas responden mengenai kebijakan pembelajaran daring dari rumah ternyata tidak membuat siswa sebagai responden kesulitan menjawab mengenai dampak positif dari pembelajaran daring yang dilaksanakan. Pembelajaran daring yang dilakukan siswa dan guru telah memudahkan kegiatan belajar di mana saja dan kapan saja, menjadikan siswa lebih peka terhadap teknologi pembelajaran, gaya belajar siswa dapat diatur sendiri, efisiensi waktu, dan siswa bisa belajar lebih tenang dan fokus. Hal ini sesuai dengan pendapat Meidawati bahwa pembelajaran daring dapat memperluas komunitas pembelajaran dan pendidik/tenaga pengajar dapat lebih mudah menemukan dan menentukan ritme pembelajaran yang tepat bagi siswa. Efisiensi waktu dan biaya dalam pembelajaran daring juga menjadi kelebihan tersendiri, dimana pendidik maupun peserta didik dapat melakukan pembelajaran jarak jauh dimana saja dan kapan saja. Siswa tidak perlu menghabiskan waktu berjam-jam untuk belajar di kelas. Bahan pelajaran dapat diakses peserta didik dengan adanya kecanggihan teknologi, sehingga siswa dapat mengunduh dan mempelajari kapan saja tanpa dibatasi ruang dan waktu

\section{SIMPULAN}

Berdasarkan kuisioner yang disebar terhadap siswa kelas 8B di SMP Negeri 44 Surabaya disimpulkan bahwa $100 \%$ siswa menjalankan pembelajaran daring di semester genap tahun akademik 2020/2021. Namun mayoritas siswa yaitu $85 \%$ lebih menyukai pembelajaran secara offline di kelas tatap muka dibandingkan pembelajaran daring. Hal ini lebih banyak disebabkan karena keterbatasan siswa untuk menyediakan kuota internet secara terus menerus, pemahaman materi kurang maksimal dan interaksi yang terbatas.

Meskipun siswa lebih memilih pembelajaran offline di kelas, terdapat media online yang paling diminati siswa saat pembelajaran daring yaitu Google Classroom (40.5\%), WhatsApp (30.5\%), Zoom (19\%) dan Microsoft Teams (10\%). Hasil penelitian survei ini dapat dijadikan sebagai dasar pelaksanaan pembelajaran daring, khususnya di SMP Newgeri 44 Surabaya. Guru dapat mempertimbangkan 
bentuk pembelajaran daring yang akan dilaksanakan selanjutnya.

\section{DAFTAR PUSTAKA}

Abidin, Z., \& Arizona, K. (2020). Pembelajaran Online Berbasis Proyek Salah Satu Solusi Kegiatan Belajar Mengajar di Tengah Pandemi COVID-19. Jurnal Ilmiah Profesi Pendidikan, 5 No.1, 64-70.

https://doi.org/10.29303/jipp.v5i1. 111.

Al Said, K. M. (2015). Students' Perceptions of Edmodo and Mobile Learning and their Real Barriers towards them. Turkish Online Journal of Educational Technology, 14(2), 167-180. https://doi.org/10.5539/elt.v8n1p1 $\underline{89}$.

Dewi, E. U., (2020). Pengaruh Kecemasan Saat Pembelajaran Daring Masa Pandemi Covid-19 Terhadap Prestasi Belajar Mahasiswa Stikes William Surabaya. Jurnal Keperawatan, 9(1), 18-23. https://doi.org/10.47560/kep.v9i1. $\underline{210}$.
Ningsih, S., (2020). Persepsi Mahasiswa Terhadap Pembelajaran Daring Pada Masa Pandemi Covid-19. JINOTEP (Jurnal Inovasi Dan Teknologi Pembelajaran): Kajian Dan Riset Dalam Teknologi Pembelajaran, 7(2), 124-132. https://doi.org/10.17977/um031v7i 22020p124.

Maskar, S., \& Wulantina, E. (2019). Persepsi Peserta Didik terhadap Metode Blended Learning dengan Google Classroom. Jurnal Inovasi Matematika, 1(2), 110-121. https://doi.org/10.35438/inomatika .$v 1 \mathrm{i} 2.156$.

Prajana, A., \& Astuti, Y. (2020). Pemanfaatan Teknologi Informasi dan Komunikasi dalam Pembelajaran oleh Guru SMK di Banda Aceh dalam Upaya Implementasi Kurikulum 2013. JINOTEP (Jurnal Inovasi Dan Teknologi Pembelajaran): Kajian dan Riset Dalam Teknologi Pembelajaran, 7(1), 33-41. https://doi.org/10.17977/um031v7i 12020p033. 
Saifuddin, M. F. (2018). E-Learning dalam Persepsi Mahasiswa. Jurnal VARIDIKA， 29(2)， 102-109. https://doi.org/10.23917/varidika.v 29i2.5637.

Shaharanee, I. N. M., Jamil, J. M., \& Rodzi, S. S. M. (2016). Google Classroom as a Tool for Active Learning. in AIP Conference Proceedings (Vol. 1761). https://doi.org/10.1063/1.4960909.

Toquero, C. M. (2020). Challenges and Opportunities for Higher Education amid the Covid-19 Pandemic: The Philippine Context. Pedagogical Research, 5(4), https://doi.org/10.29333/pr/7947.

Zamista, A. A., Rahmi, H., Sellyana, A., \& Desriyati, W. (2020). Student Perception of Calculus During Online Learning. Jurnal THEOREMS (The Original Research of Mathematics), 5(1).

Zamrotul, A., \& Durinta, P. (2015). Penggunaan Edmodo sebagai Media Pembelajaran E-Learning pada Mata Pelajaran Otomatisasi Perkantoran di SMKN 1 Surabaya.
Jurnal Pendidikan Administrasi Perkantoran (JPAP), 3(3), 1-13.

Zhafira, N. H., Ertika, Y., \& Chairiyaton. (2020). Daring Sebagai Sarana Pembelajaran Selama Masa Karantina Covid-19. Jurnal Bisnis dan Kajian Strategi Manajemen, 4(1), hal. 37-45. https://doi.org/https://doi.org/10.3 5308/jbkan.v4i1.1981. 